\title{
Effect of Utilitarian Benefit on Green Brand Equity with Green Brand Image
}

\author{
Ian Nurpatria Suryawan \\ Trisakti School of Management \\ ian.nurpatria@gmail.com
}

\begin{abstract}
The concept of Green Brand Equity (GBE) is a benchmark in determining the degree of value accumulated by green brands based on the function of green products. Many people use mineral water that is taken directly from the packaging and realize to use environmentally friendly mineral water packaging. The packaging must be easily recycled. Results shows Utilitarian Benefit (UB) has a positive effect on Green Brand Equity (GBE) mediated by Green Brand Image (GBI) based on Gender, which men and women have almost concerning for environment friendly packaging. The reason is the environment damage such as environmental pollution includes water pollution, air pollution, environmental damage eg.forest damage, erosion that causes flooding, damage to coral reefs to global warming. The effectiveness of Green Brand Equity (GBE) enhance Green Brand Image (GBI) and brand loyalty including insight environmentally friendly packaging is important to keep the safe environment.
\end{abstract}

Keywords: Utilitarian Benefit, Green Brand Equity, Green Brand Image.

\section{INTRODUCTION}

Today's, many Indonesian people, especially in the Jakarta area, have begun to have awareness to use environmentally friendly products. The reason is because the issue of environmental damage such as environmental pollution includes water pollution, air pollution, environmental damage such as forest damage, erosion that causes flooding, damage to coral reefs to global warming make many people of Jakarta are interested and highly appreciate products, especially environmentally friendly packaging. Cases of environmental pollution and disasters that are produced directly from industrial manufacturing in the world have made many people pay more attention to environmental issues (Chen and Chang, 2013a). Communities usually use environmentally friendly products with the aim of reducing damage to their environment (Chen and Chang, 2012; $2013 a ; 2013 b ; 2014)$. Based on that reason, the company must have thought about making a product that has maximum benefits for its users by making meaningful innovations, namely products that are environmentally friendly (Ahmad and Ramzan, 2018). Green Brand Image (GBI) is a breakthrough that is very important to build a brand image and positioning so that companies need to provide good service to consumers so they can immediately make a decision to buy products (Kumar, 2016). The service can be in the form of information on how to obtain products, how to use products and most importantly, 
products that are environmentally friendly where products that are environmentally friendly certainly have high quality standards, so that product quality is an adjustment of products desired by consumers, in this case products environmentally friendly (Chen and Chang, 2012; 2013a; 2013b; 2014). Many people are starting to be motivated to start a healthy lifestyle by using products that are environmentally friendly and good for their health (Chen and Chang, 2012). This opinion is supported by the website neutralNews, which contains about WWF Indonesia and Nielsen who have conducted surveys of Indonesian consumers, it turns out the results show 63\% of Indonesian consumers are willing to consume environmentally friendly products at higher prices so that it can be said that Indonesians have better awareness raising on products that are environmentally friendly and indicate the readiness of the local market to make all these thing is real (Netralnews.com, 2017). In making decisions to buy environmentally friendly products, of course men and women have different points of view, based on utility (Utilitarian Benefit) from the product itself (Tanojohardjo et al., 2014; Dagher et al., 2012; 2014; 2015), overview of brand products that are environmentally friendly (Green Brand Image) (Kang and Hur, 2012; Chen and Chang, 2012; 2013a; 2013b; 2014; Ahmad and Ramzan, 2018), which ultimately consumers have loyalty to environmentally friendly product brands (Green Brand Equity) (Chen and Chang, 2012; 2013a; 2013b; 2014).

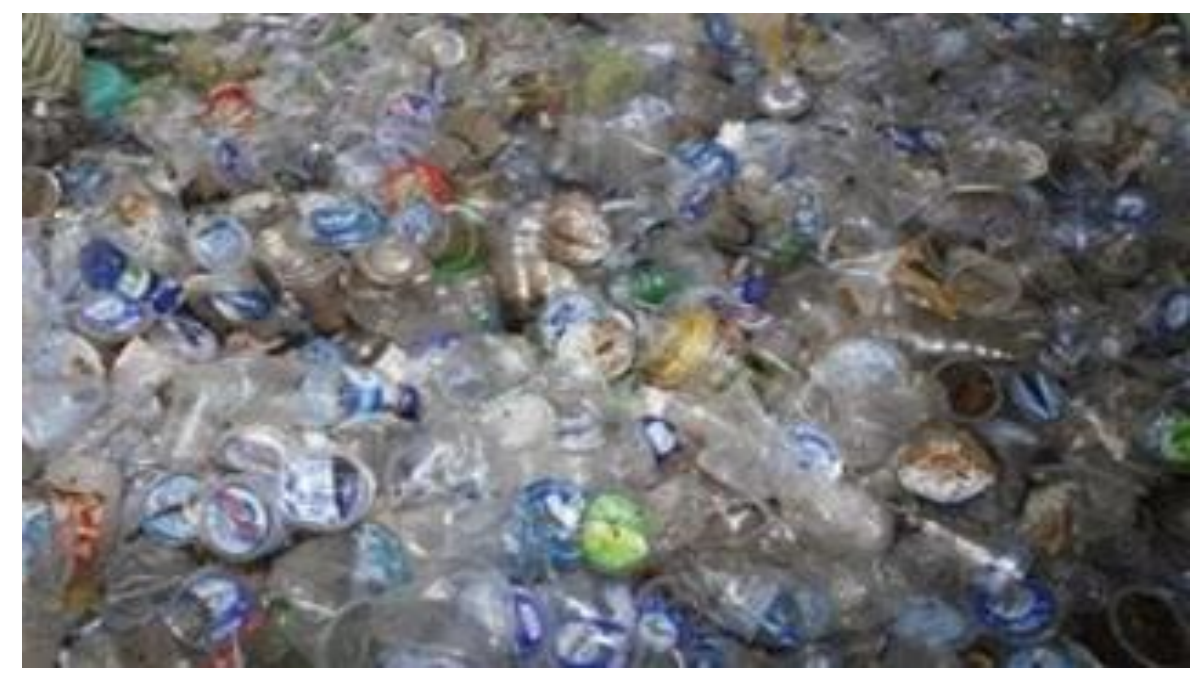

Figure 1. Plastic Waste

Source : (Katarizon.blogspot.com, 2019)

Non-biodegradable waste is very dangerous for human health and for the environment. The solution to the dangers of plastic waste is to reduce the use of plastic waste, the use of plastic material from materials that are easy to decompose by the environment and or store plastic and collected into one of the local "plastic banks" to be processed into handicrafts (katarizon.blogspot.com, 2019). Based on these conditions, companies, especially companies that produce bottled mineral water in the form of plastic bottles and plastic cups, must be environmentally friendly, meaning that the packaging, after it is no longer used, must be easily biodegradable. Actually, these conditions must 
also be supported by the behavior of the community of users in choosing environmentally friendly bottled mineral water products, meaning that the community must be smart in choosing environmentally friendly bottled mineral water products.

Actually the regulation regarding environmental preservation has been regulated according to legislation number 32/2009 concerning protection and management for the environment which has a function to maintain a good and healthy environment because it is a right for all citizens living in Indonesia, as such stipulated in Article 28H of the 1945 Constitution of the Republic of Indonesia (Point a, Considering Section). This is also emphasized in the General Provisions section of the Law concerning environmental protection and management, where every form of environmental protection and management is a systematic and integrated effort carried out by all parties in order to preserve environmental functions and prevent pollution and / or environmental damage life which includes planning, utilization, control, maintenance, supervision and law enforcement (Item 2, Article 1, Chapter 1 General Provisions, legislation number 32/2009 concerning protection and management of the environment). Specifically regarding all activities that result in environmental damage by the parties which result in direct and / or indirect changes to the physical, chemical and / or biological properties of the environment that exceed the standard criteria are also regulated by the government so that the environment can be maintained (Point 17, Article 1, Chapter 1 General Provisions, legislation number 32/2009 concerning environmental protection and management). For those who do not obey all actions, they are also mentioned and prohibited and regulated in legislation number 32/2009 concerning protection and management of the environment so that Criminal Provisions are available (Chapter XV, Criminal Provisions, Article 97 Article 120) legislation number 32 / 2009 concerning environmental protection and management.

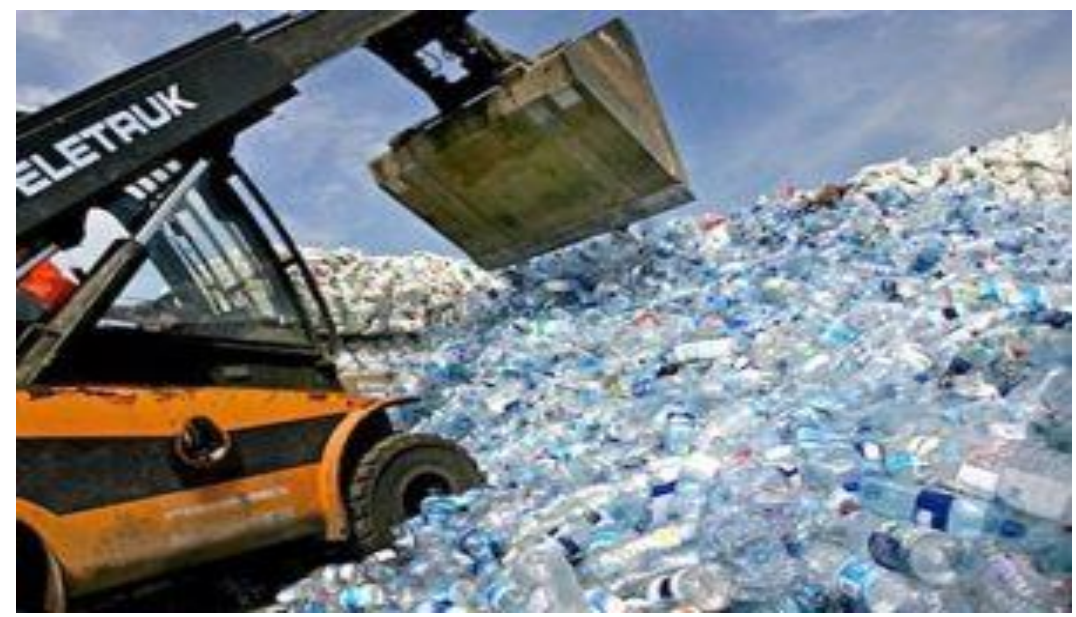

Figure 2. Stacking Plastic Waste Not Decomposed in a Landfill Source : (Jurnalasia.com, 2019)

For this reason, mineral water companies need to improve the quality of green products and a reduction in risk is needed to increase the equity of green brands, because consumers usually have imperfect and asymmetrical information so it is not easy for them 
to distinguish product quality (Chen and Chang, 2013a; 2013b). For this reason, improving the quality of green products plays an important role that can reduce the risk of sales failure. Previous studies have proven that there are differences in the decision to purchase environmentally friendly products based on gender (Dagher et al., 2015).

The object of this study is the community / consumers using environmentally friendly bottled mineral water around the Jakarta area, especially North Jakarta, West Jakarta, Central Jakarta, East Jakarta, and South Jakarta.

\section{THEORETICAL REVIEW}

The Relationship of Utilitarian Benefit (UB) to Green Brand Image (GBI). How to use an efficient and effective product is called utilitarian value, there is also an opinion regarding the utilitarian value of a product, that consumers have a source of factors for a product such as savings, so that consumers will choose products that have maximum value according to their functions and values (Tanojohardjo et al., 2014). In other words, consumers will choose products that are more affordable with the same functions, quality and capabilities. Companies must make products that have maximum benefits for their users by making meaningful innovations (Ahmad and Ramzan, 2018). In this case a meaningful innovation is if the product is environmentally friendly, so consumers in choosing environmentally friendly products get maximum appreciation if the company does so, because it can minimize the risk of environmental pollution (Waskito, 2015).

Green Brand Image (GBI) is a description of the concept along with a number of expectations from the brand that consumers remember that have a relationship with products that are environmentally friendly (Kang and Hur, 2012; Ahmad and Ramzan, 2018). Green Brand Image (GBI) is important for building brand image (brand image) and positioning so that companies need to provide good service to consumers so they can immediately make decisions to buy products (Kumar, 2016). The service can be in the form of information on how to obtain products, how to use products (Chen and Chang, 2012; 2013a; 2013b; 2014).

Environmentally friendly products certainly have high quality standards, so product quality is an adjustment of products desired by consumers, in this case products that are environmentally friendly (Chen and Chang, 2012; 2013a; 2013b; 2014). Regarding Green Brand Image $(G B I)$, for companies that undertake to meet consumer perceptions in the form of environmentally friendly products, the company has succeeded in improving its image as a Green Brand Image (GBI) (Kang and Hur, 2012; Ahmad and Ramzan, 2018). Indeed, many consumers show protection for their environment by choosing environmentally friendly products and packaging (Dagher et al., 2012; 2014; 2015).

There are results of research that state that environmentally friendly products are the main element for consumers in choosing a product and are considered to minimize risk due to the use of environmentally friendly products because consumers highly value products that are environmentally friendly, for which companies must make products that are in accordance consumers (Waskito, 2015). Research conducted by other studies also proves that products that have high utilitarian value are of high innovation value by 
creating environmentally friendly products (Kang and Hur, 2012; Chen and Chang, 2012; 2013a; 2013b; 2014; Ahmad and Ramzan, 2018) .

Based on the theories and results of previous studies, a hypothesis can be made:

\section{$\mathbf{H}_{1}$ :Utilitarian Benefit (UB) has a positive effect on Green Brand Image (GBI)}

The Relationship of Green Brand Image (GBI) to Green Brand Equity (GBE). Green Brand Image $(G B I)$ is a description of conception along with a number of expectations from brands that exist in the minds of consumers that have a relationship with products that are environmentally friendly (Kang and Hur, 2012). Companies need to provide good service to consumers in order to immediately make a decision to buy products, so it is necessary to adjust the quality of products desired by consumers, in this case products that are environmentally friendly (Kang and Hur, 2012; Chen and Chang, 2012; 2013a; 2013b; 2014; Ahmad and Ramzan, 2018). For this reason, it is necessary to make consumer perceptions that the company can sell products that are environmentally friendly, so that the company's image as a green product can be achieved (Chen and Chang, 2014). Green Brand Equity $(G B E)$ is perceived as a set of brand assets and obligations towards green commitment and attention to the environment related to brands, names, symbols that can increase or decrease the value provided by a product or service (Kang and Hur, 2012; Chen and Chang, 2012; 2013a ; 2013b; 2014; Ahmad and Ramzan, 2018). There is an investment of resources in order to improve the quality of Green Brand through increased awareness and reduced risk is very helpful to improve Green Brand Equity (GBE) (Chang and Chen, 2014). Many consumers show protection for their environment by choosing environmentally friendly products and packaging (Dagher et al., 2012; 2014; 2015). Green Marketing is a development of new construction including green image, green trust, green satisfaction and Green Brand Equity (GBE) that measures consumer-specific attitudes towards green brand initiatives (Kang and Hur, 2012; Fong et al., 2013; Chen and Chang , 2012; 2013a; 2013b; 2014; Ahmad and Ramzan, 2018).

The concept of brand equity is a benchmark in determining the degree of value accumulated by brands to products or services (Fong et al., 2013). Green Brand Equity $(G B E)$ is considered as a company resource that is reflected in the brand regarding green brands and environmental problems related to brand names, symbols and logos that can increase / decrease the value found in environmentally friendly goods and services (Chen and Chang , 2012; 2013a; 2013b; 2014). Brands of well-known products can enjoy lower information in paying for promotion costs and lower risk in increasing brand value beyond functional aspects (Fong et al., 2013). Consumers began to show protection for their environment by choosing environmentally friendly products and packaging (Dagher, et.al., 2012; 2014; 2015). For this reason, companies need to create valuable products and in this case valuable products are environmentally friendly products (Chen and Chang, 2012).

For similar research shows : Green Brand Image (GBI) has a significant influence on Green Brand Equity (GBE) (Fathia, 2015). While the results of other studies show that Green Brand Image (GBI) has a significant direct effect on Green Brand Equity (GBE), the results show that there is a direct relationship between Green Brand Image (GBI) on 
Green Brand Equity (GBE) and a percentage value of 0.159 or $15.9 \%$ and indirectly Green Brand Image (GBI) with Green Brand Equity $(G B E)$ mediated by Green Trust with a percentage value of 0.0551 or $5.51 \%$ (Kurniawan, 2013). Previous studies have proven that there are differences in the decision to purchase environmentally friendly products based on gender (Dagher et al., 2015).

Based on the theories and results of previous studies, a hypothesis can be made :

$\mathbf{H}_{2}$ :Green Brand Image (GBI) has a positive effect on Green Brand Equity (GBE)

H3 :Utilitarian Benefit $(U B)$ has a positive effect on Green Brand Equity $(G B E)$ mediated by Green Brand Image (GBI)

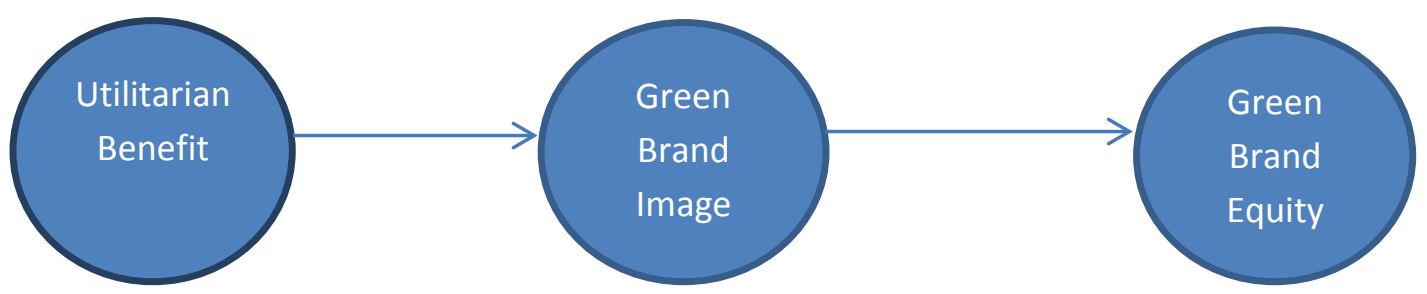

Figure 3. (Research Concept Framework, 2019)

\section{METHODOLOGY}

Methodology is an orderly and systematic way to get something to be desired (Partanto et al., 2015). There is a statement that the research method is the methods used by researchers to collect research data (Arikunto, 2013). The design of this study, refers to previous studies which are divided into indicators and variables in this study. From these studies, it was combined that both examined Green Brand Equity (GBE). This study presents the specific fields studied (Sekaran and Bougie, 2017).

The data of this study were obtained from November 2018 - December 2018 from consumers of mineral water users around the North Jakarta, Central Jakarta, West Jakarta, South Jakarta and East Jakarta regions with a total of 180 respondents. This study used quantitative research methods namely scientific research that systematic towards parts and phenomena and relationships between variables aimed at developing and using mathematical models, theories and / or hypotheses related to phenomena that occur in the community of users of environmentally friendly mineral water packaging products. This study seeks to see the effect of Utilitarian Benefit $(U B)$ on Green Brand Equity (GBE) with Green Brand Image (GBI) as a determinant by gender. In the discussion, an analysis of the positive influence of Utilitarian Benefit (UB) on Green Brand Image (GBI) was analyzed, the positive influence of Green Brand Image (GBI) on Green Brand Equity $(G B E)$ and the positive influence of Utilitarian Benefit $(U B)$ on Green Brand Equity $(G B E)$ which is mediated by Green Brand Image (GBI).

Sampling is done using simple random sampling technique, which is to determine the subject to be examined by drawing random samples directly from the population 
(Sekaran et al., 2017). Based on this, the maximum possible estimated sample size is determined to be a minimum of 5 times the number of parameters illustrated in the model, including errors (Bentler and Chou, 1987) and for data with high kurtosis values, must have a minimum sample 10 times the number of parameters (Boomsma and Hoogland, 2001) then the data analysis technique uses descriptive analysis and is processed by Analysis of Moment Structure (AMOS) software.

Table 1. Data of Respondents

\begin{tabular}{|c|c|}
\hline Profile of Respondents & Percentage \\
\hline $\begin{array}{cl}\text { Gender } & \\
\text { 1. } & \text { Male } \\
\text { 2. } & \text { Female }\end{array}$ & $\begin{array}{l}41 \% \\
59 \%\end{array}$ \\
\hline $\begin{array}{c}\text { Age } \\
\begin{array}{cl}\text { 1. } & 18-30 \text { years old } \\
\text { 2. } & 31-45 \text { years old } \\
\text { 3. } & >45 \text { years old }\end{array}\end{array}$ & $\begin{array}{l}40 \% \\
24 \% \\
36 \%\end{array}$ \\
\hline 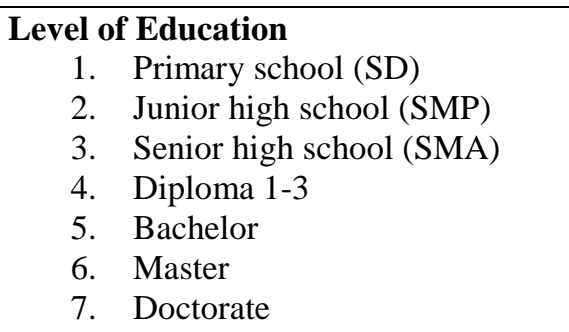 & $\begin{array}{l}2 \% \\
4 \% \\
12 \% \\
8 \% \\
62 \% \\
10 \% \\
2 \%\end{array}$ \\
\hline $\begin{aligned} \text { Work } & \\
\text { 1. } & \text { Employees } \\
\text { 2. } & \text { Government employees (PNS) } \\
\text { 3. } & \text { Teacher / Lecturer } \\
\text { 4. } & \text { Students } \\
\text { 5. } & \text { Other work }\end{aligned}$ & $\begin{array}{c}25 \% \\
20 \% \\
7 \% \\
37 \% \\
11 \%\end{array}$ \\
\hline
\end{tabular}

Source: (Survey Results, 2019)

The number of respondents is dominated by female, which is $59 \%$, the rest is male, $41 \%$. For the age range, respondents have an age range of $18-30$ years at $40 \%$, ages $31-45$ years at $24 \%$, age and above 45 years at $36 \%$. For the education level, respondents had an elementary education (Primary school/SD) level of $2 \%$, Junior high school (SMP) at $4 \%$, Senior high school (SMA) at 12\%, Diploma 1-3 at 8\%, Bachelor degree at 62\%, Master degree at $10 \%$ and Doctoral degree at $2 \%$. Respondent work was dominated by employees at $25 \%$, Government employees (PNS) at 20\%, teachers / lecturers at 7\%, students at $37 \%$, the remaining $11 \%$ are other jobs such as small and medium enterprises (SME's), housewives, and non-formal sector jobs. 
Table 2. Research Variables and Indicators

\begin{tabular}{|c|c|c|c|c|}
\hline No & $\begin{array}{l}\text { Research } \\
\text { Variable }\end{array}$ & Definition & Indicator & Scale \\
\hline 1. & $\begin{array}{c}\text { Utilitarian } \\
\text { Benefit } \\
(U B)\end{array}$ & $\begin{array}{l}\text { Efficient and effective way of using } \\
\text { the product (Tanojohardjo et al., } \\
\text { 2014). } \\
\text { For the sake of savings, consumers } \\
\text { choose more affordable products } \\
\text { according to the same functions, } \\
\text { quality and capabilities as more } \\
\text { expensive products (Tanojohardjo et } \\
\text { al., 2014). } \\
\text { Consumers in choosing } \\
\text { environmentally friendly products get } \\
\text { maximum appreciation if the } \\
\text { company does so, because it can } \\
\text { minimize the risk of environmental } \\
\text { pollution (Waskito, 2015). }\end{array}$ & $\begin{array}{l}\text { Making work easy. } \\
\text { Substitution product. } \\
\text { Products that have benefits } \\
\text { for users. }\end{array}$ & $\begin{array}{l}\text { Likert } 1 \\
-5\end{array}$ \\
\hline 2. & $\begin{array}{c}\text { Green } \\
\text { Brand } \\
\text { Image }(G B I)\end{array}$ & $\begin{array}{l}\text { It is a description of the concept } \\
\text { along with a number of } \\
\text { expectations from the brand that } \\
\text { consumers remember that have a } \\
\text { relationship with products that are } \\
\text { environmentally friendly (Kang and } \\
\text { Hur, 2012). } \\
\text { Companies need to provide good } \\
\text { service to consumers so they can } \\
\text { immediately make decisions to buy } \\
\text { products that consumers want, } \\
\text { namely environmentally friendly } \\
\text { products (Chen and Chang, 2012; } \\
\text { 2013a; 2013b; 2014). } \\
\text { Product quality that is desired by } \\
\text { consumers, in this case products } \\
\text { that are environmentally friendly } \\
\text { (Dagher et al., 2012; 2014; 2015; } \\
\text { Ahmad and Ramzan, 2018). } \\
\text { Companies that undertake to fulfill } \\
\text { consumer perceptions in the form } \\
\text { of environmentally friendly } \\
\text { products mean that the company } \\
\text { has succeeded in improving the }\end{array}$ & $\begin{array}{c}\text { Service. } \\
\text { Product quality. } \\
\text { Consumer perception }\end{array}$ & $\begin{array}{l}\text { Likert } 1 \\
-5\end{array}$ \\
\hline
\end{tabular}

Jurnal Manajemen/Volume XXIII, No. 02 June 2019: 306-320 


\begin{tabular}{|c|c|c|c|c|}
\hline & & $\begin{array}{l}\text { company's image as a Green Brand } \\
\text { Image (GBI) (Chen and Chang, } \\
\text { 2012; 2013a; 2013b; 2014) }\end{array}$ & & \\
\hline 3. & $\begin{array}{l}\text { Green } \\
\text { Brand } \\
\text { Equity } \\
(G B E)\end{array}$ & $\begin{array}{l}\text { Green Brand Equity }(G B E) \text { is stated } \\
\text { as a number of company resources } \\
\text { depicted in a special brand } \\
\text { regarding green commitments and } \\
\text { environmental issues related to } \\
\text { brand names, symbols and logos to } \\
\text { increase or decrease the value } \\
\text { derived from environmentally } \\
\text { friendly goods and services (Chen } \\
\text { and Chang, 2012; 2013a; 2013b; } \\
\text { 2014). } \\
\text { The company creates products that } \\
\text { are valuable and in this case } \\
\text { valuable products are } \\
\text { environmentally friendly products } \\
\text { (Chen and Chang, 2012; 2013a; } \\
\text { 2013b; 2014). not trust } \\
\text { Consumers do not } \\
\text { environmentally friendly company } \\
\text { activities until they are confident } \\
\text { about the benefits generated (Chen } \\
\text { and Chang, 2012; 2013a; 2013b; } \\
\text { 2014). } \\
\text { Green Brand Equity (GBE) is } \\
\text { expressed as a set of brand assets } \\
\text { and liabilities to green } \\
\text { commitments and environmental } \\
\text { concerns related to brands, names } \\
\text { and symbols that can increase or } \\
\text { decrease the value of a product or } \\
\text { service (Chen and Chang, 2012; } \\
\text { 2013a; 2013b; 2014). }\end{array}$ & $\begin{array}{l}\text { Valuable products are } \\
\text { environmentally } \\
\text { friendly products } \\
\text { Products that can } \\
\text { protect environmental } \\
\text { damage. } \\
\text { Products that have a } \\
\text { high concern for the } \\
\text { environment. }\end{array}$ & $\begin{array}{l}\text { Likert } 1 \\
-5\end{array}$ \\
\hline
\end{tabular}

Source: (Primary Data Processing, 2019) 
Table 3. Validity Test

\begin{tabular}{|c|c|c|c|c|c|}
\hline \multirow[t]{3}{*}{ Variable } & \multirow[t]{3}{*}{ Item } & \multicolumn{4}{|c|}{ Gender } \\
\hline & & \multicolumn{2}{|c|}{ Male } & \multicolumn{2}{|c|}{ Female } \\
\hline & & Estimation & Information & Estimation & Information \\
\hline \multirow{4}{*}{$\begin{array}{l}\text { Utilitarian } \\
\text { Benefit } \\
(U B)\end{array}$} & $\begin{array}{l}\text { UB1 <--- Utilitarian } \\
\text { Benefit }\end{array}$ & 0,870 & Valid & 0,822 & Valid \\
\hline & $\begin{array}{l}\text { UB2 <--- Utilitarian } \\
\text { Benefit }\end{array}$ & 0,796 & Valid & 0,919 & Valid \\
\hline & $\begin{array}{l}\text { UB3 <--- Utilitarian } \\
\text { Benefit }\end{array}$ & 0,652 & Valid & 0,729 & Valid \\
\hline & $\begin{array}{l}\text { GBI1 <--- Green Brand } \\
\text { Image }\end{array}$ & 0,766 & Valid & 0,800 & Valid \\
\hline \multirow{4}{*}{$\begin{array}{l}\text { Green } \\
\text { Brand } \\
\text { Image } \\
(G B I)\end{array}$} & $\begin{array}{l}\text { GBI } 2<--- \text { Green Brand } \\
\text { Image }\end{array}$ & 0,764 & Valid & 0,899 & Valid \\
\hline & $\begin{array}{l}\text { GBI3 <--- Green Brand } \\
\text { Image }\end{array}$ & 0,824 & Valid & 0,865 & Valid \\
\hline & $\begin{array}{l}\text { GBI4 <--- Green Brand } \\
\text { Image }\end{array}$ & 0,833 & Valid & 0,860 & Valid \\
\hline & $\begin{array}{l}\text { GBE1<--- Green Brand } \\
\text { Equity }\end{array}$ & 0,817 & Valid & 0,771 & Valid \\
\hline \multirow{3}{*}{$\begin{array}{l}\text { Green } \\
\text { Brand } \\
\text { Equity } \\
(G B E)\end{array}$} & $\begin{array}{l}\text { GBE2<--- Green Brand } \\
\text { Equity }\end{array}$ & 0,780 & Valid & 0,812 & Valid \\
\hline & $\begin{array}{l}\text { GBE3<--- Green Brand } \\
\text { Equity }\end{array}$ & 0,602 & Valid & 0,818 & Valid \\
\hline & $\begin{array}{l}\text { GBE4<--- Green Brand } \\
\text { Equity }\end{array}$ & 0,800 & Valid & 0,867 & Valid \\
\hline
\end{tabular}

Source: (Obtain Primary Data Using AMOS, 2019)

Based on table 3 Validity Test for Male Gender shows that for UB1 items of 0.870 , UB2 of 0.796 , UB3 of 0.652 , GBI1 of 0.766 , GBI2 of 0.764 , GBI3 of 0.824 , GBI4 of $0.833, \mathrm{GBE} 1$ of $0.817, \mathrm{GBE} 2$ of 0.780 , GBE3 of 0.602 , GBE4 of 0.800 . This means that to test the validity performed on each item the question of each variable is declared valid because it shows an estimate value on standardized regression weight with a minimum value of 0.5 . The next step is to perform reliability testing with the criteria, said to be reliable if the value of construct reliability $>0.7$

Validity Test for Female Gender shows that for UB1 items of 0.822, UB2 is 0.919, UB3 is 0.729 , GBI1 is 0.800 , GBI2 is 0.899 , GBI3 is 0.865 , GBI4 is 0.860 , GBE1 is 0.771 , GBE2 is 0.812 , GBE3 is 0.818 , GBE4 is 0.867 . This means that to test the validity performed on each item the question of each variable is declared valid because it shows an estimate value on standardized regression weight with a minimum value of 0.5 . The next step is to perform reliability testing with criteria, said to be reliable if the value of the reliability construct is $>0.7$. 
Table 4. Reliability Test

\begin{tabular}{|c|c|c|c|c|}
\hline \multirow[t]{3}{*}{ Variable } & \multicolumn{4}{|c|}{ Gender } \\
\hline & \multicolumn{2}{|c|}{ Male } & \multicolumn{2}{|c|}{ Female } \\
\hline & $\begin{array}{c}\text { Reliability Test } \\
\text { Results Using } \\
\text { Construct } \\
\text { Raliability }\end{array}$ & Information & $\begin{array}{c}\text { Reliability Test } \\
\text { Results Using } \\
\text { Construct } \\
\text { Raliability }\end{array}$ & Information \\
\hline $\begin{array}{c}\text { Utilitarian Benefit } \\
(U B)\end{array}$ & $\begin{array}{l}0,820 \\
0.875\end{array}$ & $\begin{array}{l}\text { Reliable } \\
\text { Reliable }\end{array}$ & $\begin{array}{l}0.865 \\
0.917\end{array}$ & $\begin{array}{l}\text { Reliable } \\
\text { Reliable }\end{array}$ \\
\hline $\begin{array}{c}\text { Green Brand Image } \\
\text { (GBI) } \\
\text { Green Brand Equity } \\
(G B E)\end{array}$ & 0.839 & Reliable & 0.890 & Reliable \\
\hline
\end{tabular}

Source: (Obtain Primary Data Using AMOS, 2019)

Based on table 4 Reliability Test Results for Male Gender, it can be seen that for UB construct reliability of $0.820, \mathrm{GBI}$ is 0.875 and GBE is 0.839 . This shows that all variables are declared reliable with the value of construct reliability $>0.7$. Reliability testing is considered reliable if the value of the reliability construct is $>0.7$.

Reliability Test Results for Female Gender, it can be seen that for UB construct reliability of 0.865 , GBI is 0.917 and GBE is 0.890 . This shows that all variables are declared reliable with the value of construct reliability $>0.7$. Reliability testing is considered reliable if the value of the reliability construct is $>0.7$.

Table 5. Normality Test

\begin{tabular}{|c|c|c|c|c|c|c|c|c|c|c|c|c|}
\hline \multirow[t]{3}{*}{ Variable } & \multicolumn{12}{|c|}{ Gender } \\
\hline & \multicolumn{6}{|c|}{ Male } & \multicolumn{6}{|c|}{ Female } \\
\hline & $\min$ & $\max$ & skew & c.r. & kurtosis & c.r. & $\min$ & $\max$ & skew & c.r. & kurtosis & c.r. \\
\hline$U B 1$ & 1.000 & 5.000 & -.890 & -3.445 & 2.135 & 4.134 & 2.000 & 5.000 & -.436 & -1.831 & -.205 & -.432 \\
\hline$U B 2$ & 1.000 & 5.000 & -.719 & -2.784 & 1.574 & 3.048 & 2.000 & 5.000 & -.228 & -.957 & -.491 & -1.032 \\
\hline UB3 & 1.000 & 5.000 & -.661 & -2.560 & .203 & .394 & 1.000 & 5.000 & -.169 & -.710 & -.188 & -.394 \\
\hline GBE4 & 1.000 & 5.000 & -.859 & -3.325 & 1.074 & 2.079 & 2.000 & 5.000 & .060 & .252 & -.966 & -2.030 \\
\hline GBE3 & 1.000 & 5.000 & -.770 & -2.984 & .598 & 1.158 & 2.000 & 5.000 & -.243 & -1.021 & -.834 & -1.752 \\
\hline GBE2 & 1.000 & 5.000 & -.796 & -3.083 & .718 & 1.390 & 2.000 & 5.000 & -.225 & -.945 & -.597 & -1.254 \\
\hline GBEI & 1.000 & 5.000 & -1.049 & -4.063 & 2.106 & 4.079 & 2.000 & 5.000 & -.244 & -1.027 & -.764 & -1.606 \\
\hline GBI4 & 1.000 & 5.000 & -.770 & -2.983 & 1.735 & 3.360 & 2.000 & 5.000 & -.008 & -.035 & -.730 & -1.533 \\
\hline GBI3 & 1.000 & 5.000 & -.776 & -3.006 & 1.692 & 3.276 & 2.000 & 5.000 & .032 & .134 & -.965 & -2.027 \\
\hline GBI2 & 1.000 & 5.000 & -.274 & -1.063 & .402 & .779 & 2.000 & 5.000 & -.137 & -.574 & -.718 & -1.510 \\
\hline GBII & 1.000 & 5.000 & -.780 & -3.020 & 1.853 & 3.587 & 3.000 & 5.000 & -.030 & -.126 & -1.171 & -2.461 \\
\hline Multivariate & & & & & 26.880 & 7.539 & & & & & 24.738 & 7.530 \\
\hline
\end{tabular}

Source: (Obtain Primary Data Using AMOS, 2019)

Based on table 5 for Normality Test results for Male Gender, showing the value of critical ratio skewness of UB1 indicator variable is -3.445 , UB2 is -2.784 , UB3 is -2.560 , GBE1 is -4.063 , GBE2 of $-3,083$, GBE3 of $-2,984$, GBE4 of $-3,325$, GBI1 of $-3,020$, GBI2 of $-1,063$, GBI3 of $-3,006$, GBI4 of $-2,983$. For the value of normal critical ratio skewness must show the results with CR value is $(-/+) 2.58$. In this case, the value of the normal critical ratio skewness is only the UB3 indicator variable of $-2,560$, GBI2 of 1,063. Multivariate kurtosis value was obtained at 26,880 with a Critical Ratio of 7.539.

Normality Test results for Female Gender, showing the value of normal critical ratio skewness which is derived from UB1 indicator variable of -1.831 , UB2 of -0.957 , UB3 of 
-0.710, GBE1 of -1.027 , GBE2 of $-0,945$, GBE3 of $-1,021$, GBE4 of 0,252 , GBI1 of 0,126 , GBI2 of $-0,574$, GBI3 of 0,134 , GBI4 of $-0,035$. For the value of normal critical ratio skewness must show the results with $\mathrm{CR}$ value is $(-/+)$ 2.58. In this case, the abnormal value of the critical ratio skewness is only the GBI2 indicator variable of -0.574 . The multivariate kurtosis value was obtained at 24,738 with a Critical Ratio of 7.530.

Table 6. Goodness of Fit Test

\begin{tabular}{l|c|c|c}
\hline $\begin{array}{c}\text { Goodness } \\
\text { of fit index }\end{array}$ & $\begin{array}{c}\text { Criteria } \\
\text { (cut-off value) }\end{array}$ & Indicator Value & Conclusion \\
\hline Chi-square $\left(\mathrm{X}^{2}\right)$ & Approach of 0 & 119,418 & Marginal Fit \\
\hline Probability & $\geq 0,05$ & 0,007 & Marginal Fit \\
\hline NFI & $\geq 0,90$ & 0,919 & Good Fit \\
\hline IFI & $\geq 0,90$ & 0,975 & Good Fit \\
\hline TLI & $\geq 0,90$ & 0,966 & Good Fit \\
\hline CFI & $\geq 0,90$ & 0,974 & Good Fit \\
\hline AGFI & $\geq 0,90$ & 0,847 & Good Fit \\
\hline RMSEA & $\leq 0,10$ & 0,047 & \\
\hline
\end{tabular}

Source: (Obtain Primary Data Using AMOS, 2019)

Based on table 6, there are results of the Goodness of Fit Test for all criteria, namely NFI of 0.919 , IFI of 0.975 , TLI of 0.966 , CFI of 0.974 , AGFI of 0.847 and RMSEA of 0.047 that have met the Goodness of Fit assessment criteria. While Chi-square in the Marginal Fit position because it is still far from 0 and the Probability value of 0.007 is still less than 0.05. A model is declared Goodness of Fit if there are one or two criteria that are considered to fulfill the requirements, then the model is said to be good so that the results of testing structural equation models are accepted and further analysis can be carried out (Ghozali, 2017).

\section{DISCUSSION}

Table 7. Influence Test

\begin{tabular}{|c|c|c|c|c|c|c|c|c|}
\hline \multirow[b]{2}{*}{ Hypothesis } & \multicolumn{8}{|c|}{ Gender } \\
\hline & \multicolumn{4}{|c|}{ Male } & \multicolumn{4}{|c|}{ Female } \\
\hline $\begin{array}{l}\mathrm{H}_{1}: \text { Utilitarian Benefit }(U B) \text { has a positive } \\
\text { effect on Green Brand Image (GBI) }\end{array}$ & 0.144 & 5.086 & $* * *$ & Supported & 0.111 & 5.842 & **** & Supported \\
\hline $\begin{array}{l}\mathrm{H}_{2} \text { :Green Brand Image }(G B I) \text { has a positive } \\
\text { effect on Green Brand Equity }(G B E)\end{array}$ & 0.139 & 7.030 & $* * *$ & Supported & 0.109 & 7.008 & $* * *$ & Supported \\
\hline
\end{tabular}

Source: (Obtain Primary Data Using AMOS, 2019)

Based on table 7 for Male Gender Influence Test Results, hypothesis test of Utilitarian Benefit (UB) has a positive influence on Green Brand Image (GBI) because it has a Construct Reliability value of 5.086 or $>1.96$ and $\mathrm{P}$-value $<0.05$, whereas for 
hypothesis test of Green Brand Image (GBI) has a positive effect on Green Brand Equity $(G B E)$ because it has a Construct Reliability value of 7.030 or $>1.96$ and P-value of < 0.05 , and for hypothesis test of Utilitarian Benefit $(U B)$ it also has a positive influence on Green Brand Equity (GBE) mediated by Green Brand Image (GBI) because it has a Construct Reliability value of 4.124 or $>1.96$ and $\mathrm{P}$-value $<0.05$. Utilitarian Benefit (UB) has a more positive effect on Green Brand Image (GBI), it will also positively influence Green Brand Equity $(G B E)$. The $\mathrm{P} * * *$ value is significant with a value of $<0.001$. The result can be concluded that all variable indicators have a significant effect.

For Female Gender Influence Test Results, hypothesis test of Utilitarian Benefit $(U B)$ has a positive influence on Green Brand Image (GBI) because it has a Construct Reliability value of 5.842 or $>1.96$ and $\mathrm{P}$-value $<0.05$, whereas for hypothesis test of Green Brand Image (GBI) has a positive effect on Green Brand Equity (GBE) because it has a Construct Reliability value of 7.008 or $>1.96$ and P-value of $<0.05$, and for hypothesis test of Utilitarian Benefit $(U B)$ it also has a positive influence on Green Brand Equity $(G B E)$ mediated by Green Brand Image $(G B I)$ because it has a Construct Reliability value of 4.489 or $>1.96$ and $\mathrm{P}$-value $<0.05$. Utilitarian Benefit $(U B)$ has a more positive effect on Green Brand Image (GBI), it will also positively influence Green Brand Equity $(G B E)$. The $\mathrm{P} * * *$ value is significant with a value of $<0.001$. The result can be concluded that all variable indicators have a significant effect.

The most important of findings regard to the statistical result is that both male and female have a concern for products that are environmentally friendly.

\section{CONCLUSION}

The results of this study provide very important implications for academics and practitioners and provide theoretical concepts to academics for the development of Management science regarding the influence of Utilitarian Benefit $(U B)$ on Green Brand Equity $(G B E)$ with Green Brand Image $(G B I)$ as a determinant by gender and can be a reference in further research on Green Brand Equity $(G B E)$.

Practically, this research is expected to be able to provide information and input to producers of environmentally friendly bottled water products on how much influence from Utilitarian Benefit $(U B)$ on Green Brand Equity $(G B E)$ with Green Brand Image (GBI) as determinants based gender. Previous studies have proven that there are differences in the decision to purchase environmentally friendly products based on gender (Dagher, et.al., 2015).

In this study providing knowledge about Female gender is more concerned with packaging of mineral water that is environmentally friendly compared to Male gender even though Male also have concern for packaging of mineral water that is environmentally friendly. This study proposes an effective solution to increase the effectiveness of Green Brand Equity $(G B E)$ in enhancing Green Brand Image (GBI) and brand loyalty by adding insight that environmentally friendly packaging is very important to keep the environment safe for the community using bottled mineral water for male gender male and female gender from all walks of life (age, education and work). 
Although the effectiveness of Green Brand Equity (GBE) is based on functional benefits and emotional benefits, the results of calculations from AMOS software show that Utilitarian Benefit (UB) has a positive effect on Green Brand Equity (GBE) mediated by Gender based Green Brand Image (GBI), which means men Male and Female have almost the same concern for environmentally friendly mineral water packaging products. For Female, the results of the Influence Test are greater than Male but still care about environmentally friendly mineral water packaging products. In this case, Female have a higher level of awareness than Male to use environmentally friendly mineral water packaging products. For this reason, companies must provide superior product functionality to strengthen green brand associations for consumers who are very friendly users of bottled mineral water. to the environment.

But for this study, it does not describe the condition of the Indonesian people as a whole for users of bottled mineral water. In future research, researchers should be able to add behavioral variables, average income and other variables related to the role of gender in making decisions to use bottled mineral water that is safe for the environment in other areas outside Jakarta, because the Jakarta area does not represent the population Indonesia as a whole.

\section{REFERENCES}

Ahmad, Naveed and Ramzan, Iram (2018), "The Relationship of Green Product Innovation Performance With Corporate Competitive Advantage and Brand Image", Arabian Journal of Business and Management Review (Kuwait Chapter), 7(2), 4250, DOI: $10.12816 / 0046068$.

Arikunto, Suharsimi (2013), "Prosedur Penelitian : Suatu Pendekatan Praktek", Jakarta : Rineka Cipta, 136.

Bentler, P.M. and Chou, C.P. (1987), "Practical issues in structural modeling". Sociological Methods and Research 16, 78-117.

Boomsma, A. and Hoogland, J.J. (2001),"The robustness of LISREL modeling revisited. In: Cudeck, R., du Toit, S.,Sorbom, D. (Eds.), Structural Equation Modeling: Present and Future". Scientific Software International, Chicago, 139-168.

Chen, Y.S. and Chang, C.H.(2012), "Enhance Green Purchase Intentions : The Roles of Green Perceived Value, Green Perceived Risk, \& Green Trust". Management Decision, 50(3), 502-520.

Chen, Y.S. and Chang, C.H. (2013a), "Towards Green Trust", Management Decision, 51(1), 63-82.

Chen, Y.S. and Chang, C.H. (2013b), "Greenwash and Green Trust: The Mediation Effects of Green Consumer Confusion and Green Perceived Risk", Journal of Business Ethics, 114(3), 489-500.

Chang, C.H. and Chen, Y.S. (2014),"Managing Green Brand Equity: The Perspective of Perceived Risk Theory". Qual Quant 48:1753-1768, DOI 10.1007/s11135-0139872-y. 
Dagher, G.K.and Itani, O. (2012), "The Influence of Environmental Attitude, Environmental Concern and Social Influence on Green Purchasing Behavior",Review of BusinessResearch,12(2), 104-111.

Dagher, G.K., and Itani, O. (2014), "Factors Influencing Green Purchasing Behaviour:Empirical Evidence from the Lebanese Consumers", Journal of Consumer Behaviour, 13(3),188-195 http://dx.doi.org/10.1002/cb.1482.

Dagher, G.K., Itani, O., and Kassar, Abdul N. (2015), "The Impact of Environment Concern and Attitude on Green Purchasing Behavior: Gender as The Moderator", Contemporary Management Research, 11(2), 179-206, DOI:10.7903/cmr.13625.

Fathia, C.N. (2015), "Pengaruh Green Brand Image Terhadap Green Brand Equity dengan Green Satisfaction Sebagai Variable Mediasi Pada Produk The Body Shop di Kota Banda Aceh”. Skripsi. Fakultas Ekonomi Universitas Syiah Kuala.

Fong, But, M.M., Khong, K.W. and Ong, F.S.(2013),“Antecedents of Green Brand Equity: An Integrated Approach", Journal Business Ethics, Springer, DOI 10.1007/s10551-013-1689-z.

Ghozali. Imam. (2017), "Model Persamaan Struktural : Konsep dan Aplikasi Dengan Program AMOS 24 (Update Bayesian SEM)". Penerbit : Universitas Diponegoro. Semarang.

http://www.jurnalasia.com/ragam/dampak-sampah-plastik /, diakses 18-01-2019. http://katarizon.blogspot.com/2012/03/makalah-kimia-2009.html, diakses 18-01-2019. http://www.netralnews.com/news/nasional/read/102687/63, diakses 18-09-2017.

Kang, S. and Hur, W.H. (2012), "Investigating the Antecedents of Green Brand Equity: A Sustainable Development Perspective", Corporate Social Responsibility and Environmental Management, 19(5), 306-316.

Kumar, P. (2016), "State of Green Marketing Research over 25 years (1990-2014) Literature Survey and Classification", Marketing Intelligence \& Planning, 34(1), 137-158.

Kurniawan, H. (2013), “Pengaruh Green Brand Image terhadap Green Brand Equity: Green Trust sebagai variabel Mediasi (Studi Kasus Air Mineral Ades pada Mahasiswa Universitas Kristen Maranatha)", Skripsi. Fakultas Ekonomi Universitas Kristen Maranata.

Partanto, Pius A. dan Al Barry,M. Dhalan (2015), "Kamus Ilmiah Populer”, Surabaya : CV Arkola, 461.

Sekaran, Uma and Bougie, Roger (2017), "Research Methods for Business 7E WileyPlus Learning Space Student Package”, John Wiley and Sons Ltd., 271.

Tanojohardjo, G.Aditya, Y.S. Kunto, danR.K.M.R. Brahmana. (2014), “Analisa Hedonic Value \& Utilitarian Value Terhadap Brand Trust dengan Brand Satisfaction Sebagai Variabel Intervening Pada Produk Pewarnaan L'oreal Professionnel",Jurnal: Manajemen Pemasaran Petra, 2(1), 1-11.

Undang-Undang 32/ (2009) tentang perlindungan \& pengelolaan lingkungan hidup . Waskito, Jati (2015), "Upaya Meningkatkan Niat Pembelian Produk Ramah Lingkungan Melalui Nilai, Risiko \& Kepercayaan Terhadap Produk Hijau", Jurnal Etikonomi, 14(1), 1-16. 